\title{
Correction to: PERioperative Fluid Management in Elective ColecTomy (PERFECT) - a national prospective cohort study
}

\author{
Irish Surgical Research Collaborative ${ }^{1}$
}

Published online: 3 July 2019

(C) Royal Academy of Medicine in Ireland 2019

\section{Correction to: Irish Journal of Medical Science (2019)}

https://doi.org/10.1007/s11845-019-02003-w

The above article originally published with Christina Fleming and Irish Surgical Research Collaborative listed in the authorship line. Christina Fleming's name was included in error by the Publisher, and should have instead been included in the Collaborators section. No further changes have been made to the article. The original article has been corrected.

Publisher's note Springer Nature remains neutral with regard to jurisdictional claims in published maps and institutional affiliations.

The online version of the original article can be found at https://doi.org/ 10.1007/s11845-019-02003-w

Irish Surgical Research Collaborative ISRC@rcsi.com

1 Irish Surgical Research Collaborative, Royal College of Surgeons in Ireland, 123, St. Stephen's Green, Dublin 2, Ireland 